\title{
Correction
}

\section{Correction: The Impact of Policy Guidelines on Hospital Antibiotic Use over a Decade: A Segmented Time Series Analysis}

\section{The PLOS ONE Staff}

There is an error in Table 3. In the first column, there is a spacing error that resulted in merged rows. Please see the corrected Table 3 here.

Table 3. Pair-wise segmented analysis as the estimated rate of change in monthly DDD/100 bed days for adjacent segments and predicted values for the start of the $i$-segment, start and end of the $i+1$-segment.

\begin{tabular}{|c|c|c|c|c|}
\hline $\mathbf{S}^{*}$ & $\begin{array}{l}\text { Slopes (SE) for two adjacent } \\
i \text {-segment and } i+1 \text {-segments }\end{array}$ & $\begin{array}{l}\text { Predicted values for the start of the } \\
i \text {-segment, start and end of the } i+1 \text {-segment }\end{array}$ & $\mathbf{R}^{2}$ & $p$ value $\mathrm{e}^{* *}$ \\
\hline $\begin{array}{l}1 \\
2\end{array}$ & $\begin{array}{l}0.708(0.120) \\
0.010(0.107)\end{array}$ & $57.88,74.23$ and 73.01 & 0.61 & $\begin{array}{l}<0.001 \\
0.926\end{array}$ \\
\hline $\begin{array}{l}2 \\
3\end{array}$ & $\begin{array}{l}0.265(0.088) \\
0.362(0.050)\end{array}$ & $71.32,77.35$ and 89.39 & 0.73 & $\begin{array}{l}0.004 \\
<0.001\end{array}$ \\
\hline $\begin{array}{l}3 \\
4\end{array}$ & $\begin{array}{l}0.362(0.050) \\
0.036(0.075)\end{array}$ & $79.70,89.58$ and 90.63 & 0.59 & $\begin{array}{l}<0.001 \\
0.629\end{array}$ \\
\hline $\begin{array}{l}4 \\
5\end{array}$ & $\begin{array}{l}0.067(0.072) \\
-0.401(0.089)\end{array}$ & $89.15,90.35$ and 79.31 & 0.55 & $\begin{array}{l}0.357 \\
<0.001\end{array}$ \\
\hline
\end{tabular}

\section{Reference}

1. Chandy SJ, Naik GS, Charles R, Jeyaseelan V, Naumova EN, et al. (2014) The Impact of Policy Guidelines on Hospital Antibiotic Use over a Decade: A Segmented Time Series Analysis. PLoS ONE 9(3): e92206. doi:10.1371/ journal.pone.0092206 